\title{
Hydrogen peroxide generation with immobilized glucose oxidase for textile bleaching
}

\author{
Tzanko Tzanov a, Silgia A. Costa ${ }^{\mathrm{a}}$, Georg M. Gübitz ${ }^{\mathrm{b}}$, \\ Artur Cavaco-Paulo a,* \\ a Textile Engineering Department, Campus de Azurem, University of Minho, 4800 Guimarães, Portugal \\ ${ }^{\mathrm{b}}$ Department of Environmental Biotechnology, Graz University of Technology, 8010 Graz, Austria
}

Received 26 February 2001; received in revised form 24 July 2001; accepted 15 August 2001

\begin{abstract}
Glucose oxidase was covalently immobilized on commercially available alumina and glass supports, with a high level of protein recovery. The operational stability of the alumina carrier was an advantage over the glass support, though the rate of generation of hydrogen peroxide in the case of the latter was higher. The immobilization technique provided repeated application of the enzyme even in low concentration, and the hydrogen peroxide generated in the enzymatic reaction was successively used for textile bleaching. (C) 2002 Elsevier Science B.V. All rights reserved.
\end{abstract}

Keywords: Glucose oxidase; Immobilization; Hydrogen peroxide; Textile bleaching

\section{Introduction}

The textile technology for preparation of cellulosic fiber materials aiming to improve their performance in further finishing stages comprises several consecutive operations, i.e. desizing, scouring and bleaching. The whitening of the textiles is achieved with different oxidizing or reducing agents, capable of destroying the natural pigments and matter present in the fibers. Nowadays the hydrogen peroxide, due to its biodegradability,

\footnotetext{
* Corresponding author. Tel.: + 351-253-510280; fax: + 351-253-510293.

E-mail address: artur@eng.uminho.pt (A. Cavaco-Paulo).
}

almost entirely replaced the conventional chlorine oxidizing chemicals (Weck, 1991; Spirro and Criffith, 1997). Hydrogen peroxide precursors, such as perborates and percarbonates are incorporated in a major part of commercially available detergent compositions. Alternatively, hydrogen peroxide could be produced enzymatically by glucose oxidase catalyzed conversion of glucose in the presence of oxygen in aqueous solutions (Schacht et al., 1995). Similar enzymatic systems were used as constituents in detergent formulations, to generate controlled rates of hydrogen peroxide (Pramod, 1994; Van der Helm et al., 1998). The gluconic acid formed in the enzyme reaction acts as a chelator for metal ions and the addition of peroxide stabilizing agents may be avoided. Im- 
plementation of enzymatic systems in cotton pretreatment is beneficial in terms of decreased water, and chemical consumption, i.e. reusing the desizing waste baths as additional source for glucose, and decrease of the waste water pollution. However, no bleaching process using enzymatically-produced peroxide is industrially available up to now, and one reason is that the enzymes are still quite expensive products. Their recycling and multiple use could be ensured using the existing enzyme immobilization techniques. Enzymes have been immobilized on various insoluble carriers for wide number of research, diagnostics, food, pharmaceutical, medical, and industrial applications. Immobilization provides long-term application of the enzyme at lower process cost, coming from the easy recovery and recycling, the reduced enzyme dosage, and the suitability to continuous operations. The methods of immobilization include adsorption, ionic and covalent binding, and the latter are most appropriate when the enzyme will be used in drastic environments and high stabilities are required. Glucose oxidases have been immobilized on polyethylene-g-acrylic acids graft copolymer membranes (Hsiue and Wang, 1990), silicone supports (Subramanian et al., 1999), silk fibroin membranes (Asakura et al., 1988), activated carbon, glass, collagen, polycarbonate, polyurethane, polypyrrole films, cellulose, etc. (Taylor, 1985, 1991), mainly for application as electrochemical biosensors (Wilson and Turner, 1992). To our knowledge the application of immobilized glucose oxidase for production of hydrogen peroxide for textile bleaching has not been reported. In the present research glucose oxidase was immobilized on two silanized porous supports, alumina and glass, using glutaraldehyde as crosslinking agent. Glass is recommended as carrier at $\mathrm{pH}$ lower than 7 , while alumina support, which showed to be suitable for catalase immobilization in our previous research in the textile field (Costa et al., 2001), is stable in the pH-range of pH 5-11 (Messing, 1976). The enzymatic reaction of glucose oxidase and glucose requires slightly acidic medium. The objective of this study is to establish a lower cost bleaching process for cellulosic textile materials with enzymatically generated hydrogen peroxide.

\section{Materials and methods}

\subsection{Textile substrate}

The textile material used in the experiments was scoured, plain-woven $100 \%$ cotton fabric, $120 \mathrm{~g}$ $\mathrm{m}^{-2}$.

\subsection{Enzymatic production of hydrogen peroxide}

Production of hydrogen peroxide by immobilized glucose oxidase (EC 1.1.3.4) from Aspergillus niger (Sigma), and $\mathrm{D}(+)$-Glucose (Merck) proceeded at $\mathrm{pH} 5$, and $35{ }^{\circ} \mathrm{C}$ in $0.1 \mathrm{M}$ acetate buffer, with constant aeration $\left(51 \mathrm{~min}^{-1}\right)$ through glass tube introduced into the solution, and stirring, until sufficient level of peroxide concentration was reached. The concentration of hydrogen peroxide was detected by potassium permanganate titration in acidic medium (Interox Chemicals, 1980).

\subsection{Glucose oxidase immobilization}

Alumina support (aluminium oxide pellets, 3 $\mathrm{mm}$ diameter, bulk density $370 \mathrm{~g}^{-1}$ ) was obtained from Aldrich, and glass support was provided by Sampt-Poraver $\mathrm{GmbH}$, Austria (glass foam pellets, $4 \mathrm{~mm}$ diameter, a bulk density of $160 \mathrm{~g}^{-1}$, marketed for application in civil engineering). The supports were silanized by immersing them in $4 \% \quad(\mathrm{v} / \mathrm{v})$ solution of $\gamma$-aminopropyltriethoxy silane (Sigma) in acetone at $45{ }^{\circ} \mathrm{C}$ for $24 \mathrm{~h}$. The silanized pellets were thoroughly washed with distilled water and immersed in $2 \%(\mathrm{v} / \mathrm{v})$ of aqueous glutaraldehyde (Aldrich) solution for $2 \mathrm{~h}$ at room temperature, after being washed with distilled water and dried in a oven at $60{ }^{\circ} \mathrm{C}$ for $1 \mathrm{~h}$ (Vasudevan and Thakur, 1994). Thereafter, $3 \mathrm{~g}$ pellets were immersed in $25 \mathrm{ml}$ of the enzyme preparation for 16 $\mathrm{h}$ at room temperature. Multiple washing to eliminate the non-fixed protein follows the immobilization procedure.

\subsection{Protein assay}

The amount of protein in the supernatant solu- 
tion after immobilization was determined according to the Bradford method (Bradford, 1976), using bovine serum albumin (BSA) as protein standard. Protein recovery (\%) was calculated as a ratio between the amount of protein added into the immobilization mixture and the protein remaining in solution, and desorbed during washing. From the results for the protein recovery the amount of bound protein per weight of support was calculated.

\subsection{Bleaching process}

The conventional bleaching solution contained as percentage of weight of fabric: silicate $3.5 \%$, soda ash $1 \%$, sodium hydroxide $1 \%$, and $35 \%$ hydrogen peroxide- $4 \%\left(0.17 \mathrm{~g} \mathrm{l}^{-1} 100 \% \mathrm{H}_{2} \mathrm{O}_{2}\right.$ in the bleaching mixture). Trials to activate the enzymatically produced peroxide were performed in three ways: $\mathrm{pH} 11$ at $95{ }^{\circ} \mathrm{C}$ (classical approach); peroxidase (E.C. 1.11.1.7) from Horseradish (Sigma), $0.1 \mathrm{mg} 1^{-1}, \mathrm{pH} \mathrm{5,} 55{ }^{\circ} \mathrm{C}$ (Morita and Ito, 1996; Damhus et al., 1991), and sodium persulfate $10 \mathrm{~g}^{-1}, \mathrm{pH} 11$, room temperature (Letcher et al., 1994). The bleaching experiments were carried out for $1 \mathrm{~h}$ in an Ahiba
Spectradye Dyeing apparatus (Datacolor International).

\subsection{Fabric whiteness}

The whiteness of the bleached fabrics (CIE whiteness, represented in CIE units) was determined using a reflectance measuring Datacolor apparatus at standard illuminant $\mathrm{D}_{65}(\mathrm{LAV} / \mathrm{Spec}$. Incl., $\mathrm{d} / 8, \mathrm{D}_{65} / 10^{\circ}$ ).

All the determinations in this study were performed in triplicate and the results represents mean values with less than $2 \%$ of error.

\section{Results and discussion}

\subsection{Generation of hydrogen peroxide from free glucose oxidase}

At constant aeration, $\beta$-D-glucose was oxidized by the free glucose oxidase yielding D-gluconic acid and hydrogen peroxide using oxygen from the air as electron acceptor (Fig. 1). The enzymatic reaction-time curve reached a plateau probably due to a decrease in substrate concentra-

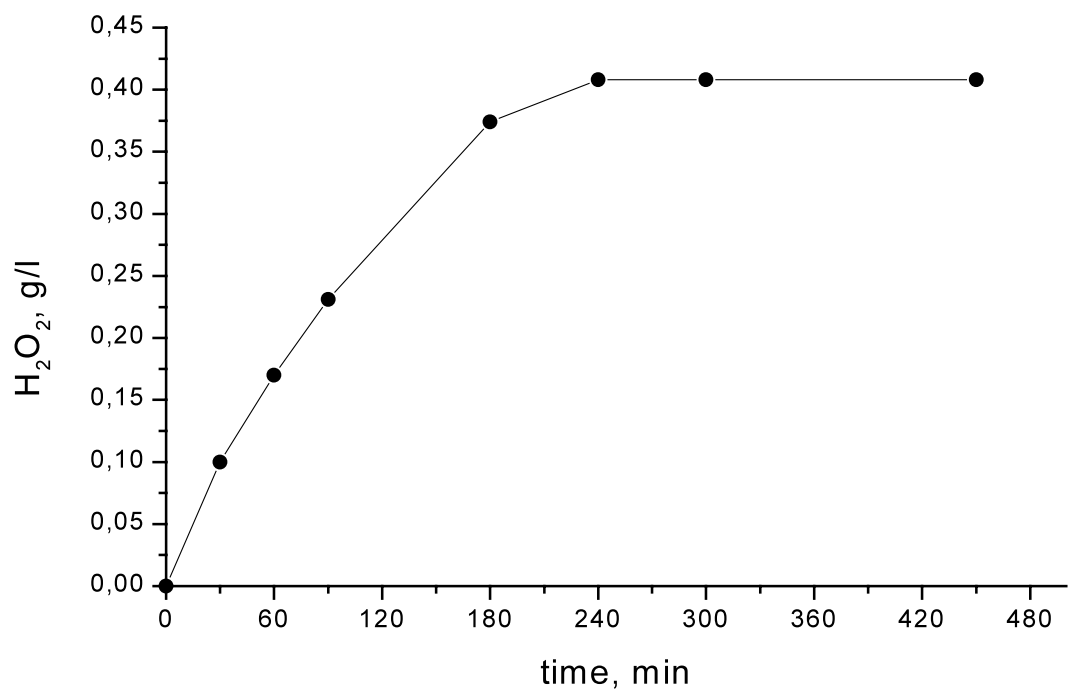

Fig. 1. Time course of peroxide production from $20 \mathrm{~g}^{-1}$ glucose and $0.04 \mathrm{mg} \mathrm{ml}^{-1}$ glucose oxidase in $50 \mathrm{ml}$ acetate buffer, pH $5,35{ }^{\circ} \mathrm{C}$, and aeration $51 \mathrm{~min}^{-1}$. 
Table 1

Protein recovery in the enzyme immobilization

Supernatant concentration after immobilization $\left(\mathrm{mg} \mathrm{ml}^{-1}\right)$

Protein recovery $(\%)$

\begin{tabular}{lllll}
\hline & Glass & Alumina & Glass & Alumina \\
\hline Concentration 1 & 0.056 & 0.073 & 72 & 64 \\
Concentration 2 & 0.100 & 0.120 & 75 & 70 \\
Concentration 3 & 0.135 & 0.189 & 83 & 72.2 \\
Concentration 4 & 0.240 & 0.320 & 82.8 & 77.1 \\
\hline
\end{tabular}

tion or inactivation of the enzyme during the time. Inactivation of the free enzyme could be caused by foaming in aerated solution or by shear forces during stirring (Thomas and Dunnill, 1979) or by high concentration of hydrogen peroxide formed during the reaction. As we reported previously (Tzanov et al., 2001a,b), higher quantities of enzymatically-produced peroxide were needed to achieve the same bleaching effect as in the standard bleaching process where hydrogen peroxide is added. Possibly, the added glucose protects the cotton from being bleached, acting as a substrate for bleaching and oxidation, thereby consuming the peroxide, or as a stabilizer. On the other hand with the increase of the bleaching process temperature the protein denaturates and transition from globular to random coil, open structure occurs. Deposition of the denaturated protein on fabric surface, due to hydrophobic fabric-enzyme interaction is possible (Tzanov et al., 2001a,b), and thereby the fabric could be protected from the bleaching action of the peroxide. These problems could be overcome by using immobilized instead of free enzyme.

\subsection{Glucose oxidase immobilization}

The immobilization procedure resulted in high levels of protein recovery for both supports (Table 1). The increase of the amount of the immobilized glucose oxidase was almost proportional to the increase of the protein concentration, and up to the studied concentration in the reaction mixture saturation of the supports was not observed. The kinetic profile of the bound enzyme was evaluated allowing it to react with the substrate (Mattiasson and Mosbach, 1976). Aliquots of the reaction mixture were removed at different time intervals, and the generation of the product was measured by permanganate titration, and compared with the free enzyme.

\subsection{Production of hydrogen peroxide from glucose immobilized on alumina support}

In the performance of the glucose oxidase immobilized on alumina (Fig. 3) an interesting phenomenon, also reported elsewhere (Oliveira et al., 2000; Bosley and Peilow, 1997), was observedhigher enzyme loadings on the support (Fig. 2) did not give higher levels of hydrogen peroxide. This could be explained by the fact that the amount of protein bound may not correlate with the activity recovered after immobilization (Taylor, 1985). The binding of the glucose oxidase onto the support normally results in significant alterations of enzyme conformation and microenvironment (Soares et al., 1999). Fluorescence microscopy studies of sliced alumina pellets (Vasudevan and Thakur, 1994) showed that the location of the immobilized protein was in the outer shell of the pellet, and concentration gradient existed inside the pellet, thus not all the pore volume is efficiently accessible for immobilization. From the above considerations we can assume that the higher the binding capacity on alumina carrier the higher should be the steric interference, since the outer shell distribution of the enzyme forces a multilayer adsorption, which inhibits the access of the substrate to the protein active sites. In fact the alumina pellets we used were fairly large ( $3 \mathrm{~mm}$ diameter) and internal pore diffusion 
must be a problem. Though the saturation of the support was not reached for the studied concentrations, further addition of enzyme was not efficient possibly due to steric hindrance of the adsorbed protein itself and the matrix. The fact that the already low protein amounts on the alumina carrier were able to convert most of the substrate has a practical significance, since suffi- cient quantity of peroxide for bleaching can be produced with low enzyme concentration.

\subsection{Production of hydrogen peroxide from glucose oxidase immobilized on glass support}

As a whole the rate of peroxide generation (Figs. 3 and 4) from the immobilized protein

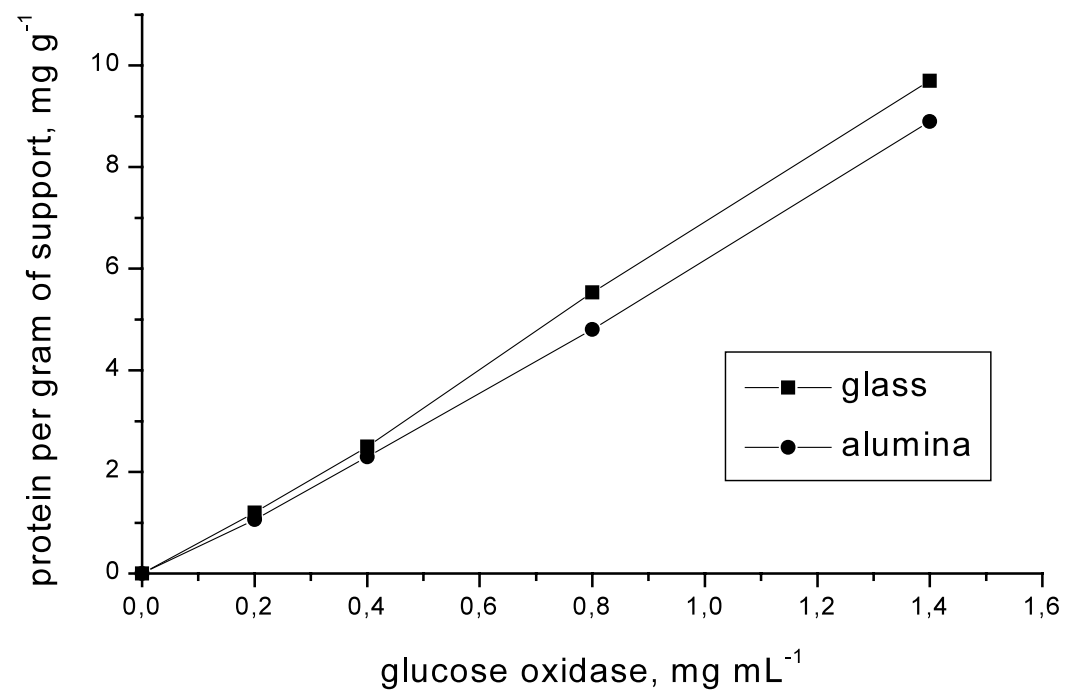

Fig. 2. Saturation of the alumina and glass supports by glucose oxidase, as a function of the enzyme concentration in the supernatant solution.

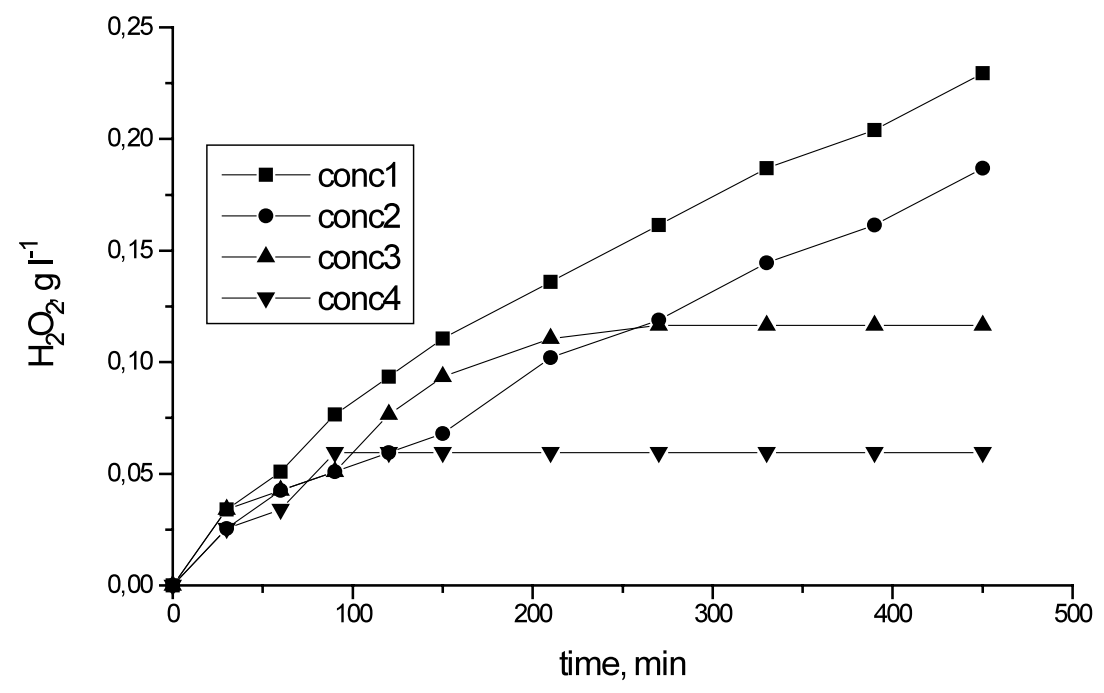

Fig. 3. Time course of peroxide generation from different amounts of glucose oxidase immobilized on $3 \mathrm{~g}$ alumina support and 20 $\mathrm{g}^{-1}$ glucose in $50 \mathrm{ml} 0.1 \mathrm{M}$ acetate buffer, $\mathrm{pH} 5,35^{\circ} \mathrm{C}$, aeration $51 \mathrm{~min}^{-1}$. Protein per support: $1.06 \mathrm{mg} \mathrm{g}-1 ; 02.3 \mathrm{mg} \mathrm{g}^{-1}$; $\Delta 4.8 \mathrm{mg} \mathrm{g}^{-1} ; \boldsymbol{\nabla} 8.9 \mathrm{mg} \mathrm{g}^{-1}$. 


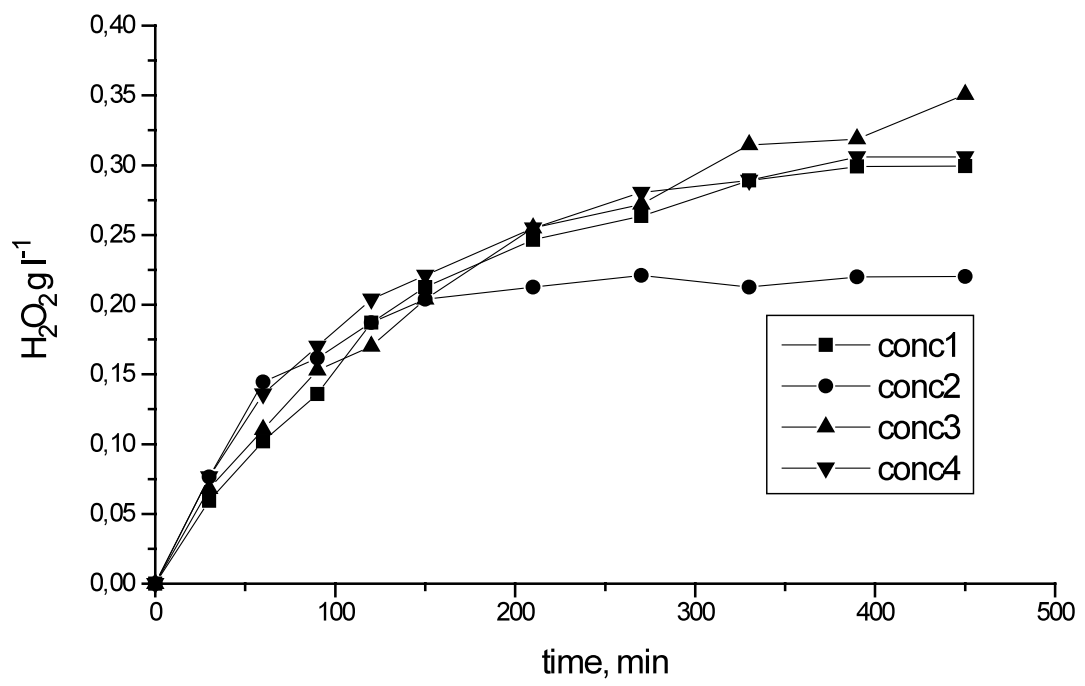

Fig. 4. Time course of peroxide generation from different amounts of glucose oxidase immobilized on $3 \mathrm{~g}$ glass support and $20 \mathrm{~g}$ $1^{-1}$ glucose in $50 \mathrm{ml} 0.1 \mathrm{M}$ acetate buffer, $\mathrm{pH} 5,35^{\circ} \mathrm{C}$, aeration $51 \mathrm{~min}^{-1}$. Protein per support: $1.2 \mathrm{mg} \mathrm{g}^{-1} ; \mathbf{O}^{2.5} \mathrm{mg} \mathrm{g}^{-1}$; $\Delta 5.53 \mathrm{mg} \mathrm{g}^{-1} ; \boldsymbol{\nabla} 9.7 \mathrm{mg} \mathrm{g}^{-1}$.

decreased nearly 2-fold compared with the free enzyme (Fig. 1). Obviously, the glucose oxidase immobilized on glass support is more accessible for the enzyme reaction due to the larger internal pore volume of the glass pellets. It is known that the diffusion constraint is one of the most dominant effects influencing the performance of the immobilized enzyme (Hartmeier, 1986). The glass support bound a higher percentage of enzyme and its rate of peroxide production is faster than for the alumina immobilization. However, the glass foam carrier appeared to have low resistance to prolonged dynamic operations, such as the peroxide production in water medium with high turbulence caused by the stirring and aeration, and dissolved partially, what in turns makes it inappropriate for repeated application. The alumina support showed good resistance at the same reaction conditions and was selected for further recycling experiments.

\subsection{Multiple use of the immobilized enzyme}

The immobilized enzyme showed good operational stability, and was reusable for at least three cycles, each of them with duration $7.5 \mathrm{~h}$, without significant loss in activity (Fig. 5). Between the trials the washed-off support was kept overnight in buffer $\mathrm{pH} 5$, at $4{ }^{\circ} \mathrm{C}$. The prolonged storage had a clear influence on the enzyme activity, which was the case in the fifth assay with the immobilized enzyme, carried out with 1-week delay after the fourth one.

\subsection{Bleaching with enzymatically produced hydrogen peroxide}

After the enzymatic production of hydrogen peroxide, the solution was used for bleaching of cotton fabrics. Addition of stabilizing agents to the bleaching bath was not necessary, since the gluconic acid produced in the enzymatic reaction acts as a stabilizer. From the approaches applied for activation of the peroxide for bleaching - alkaline, persulfate, or peroxidase, just the alkaline activation resulted in high whiteness values, comparable to the whiteness level reached in standard bleaching process (Table 2). The application of immobilized instead of free enzyme slightly increased the whiteness, eliminating the effect of the protein present in the bleaching liquor. The whiteness level reached in persulfate or peroxidase activated bleaching process, though not appropriate for white textiles, could be sufficient for dyeing in 
dark shades, and has the advantages of low energy consumption and milder process conditions. The feasibility of this lab scale process for industrial application will depend on the specific technology cycle adopted in the textile plant, and on the available machinery. The increase of the recycling capacity of the enzyme by appropriate known stabilization techniques, the engineering of the approach for application of the immobilized catalyst, and the reuse of residual desizing bath as additional source for glucose (Tzanov et al., 2001a,b), might realize significant water, energy and chemicals savings.

\section{Conclusions}

When choosing a support for enzyme immobilization for industrial application, the most important criteria are the stability of the carrier and the cost. In this study glucose oxidase was covalently immobilized on two inexpensive, commercially available porous carriers - alumina and glass. In the immobilization procedure high recovery of the protein was achieved. Sufficient bleaching levels of peroxide production could be reached with low enzyme concentration. The glass support due to its more porous morphology, bound more

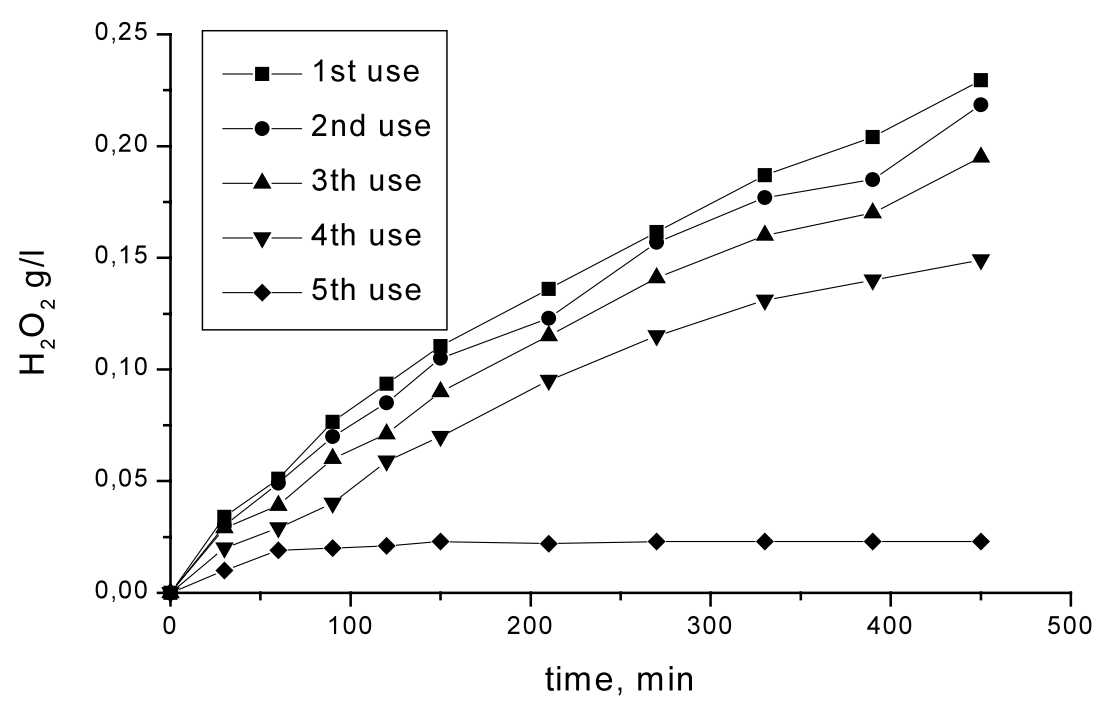

Fig. 5. Time course of hydrogen peroxide production in repeated use of glucose oxidase immobilized on $3 \mathrm{~g}$ alumina support (protein per support: $1.06 \mathrm{mg} \mathrm{g}^{-1}$ ) and $20 \mathrm{~g} \mathrm{1}^{-1}$ glucose in $50 \mathrm{ml} 0.1 \mathrm{M}$ acetate buffer, $\mathrm{pH} 5,35{ }^{\circ} \mathrm{C}$, aeration $51 \mathrm{~min}^{-1}$.

Table 2

CIE whiteness of the hydrogen peroxide bleached fabrics

\begin{tabular}{|c|c|c|c|c|c|c|}
\hline & \multirow[t]{3}{*}{ Scoured fabric } & \multirow{3}{*}{$\begin{array}{l}\text { Standard } \mathrm{H}_{2} \mathrm{O}_{2} \\
\left(0.17 \mathrm{~g} \mathrm{l}^{-1}\right) \\
\text { bleaching }\end{array}$} & \multicolumn{4}{|c|}{ Bleaching with $\mathrm{H}_{2} \mathrm{O}_{2}\left(0.30 \mathrm{~g} \mathrm{l}^{-1}\right)$ generated from } \\
\hline & & & \multirow{2}{*}{$\begin{array}{l}\text { Free enzyme } \\
\mathrm{pH} 11,95^{\circ} \mathrm{C}\end{array}$} & \multicolumn{3}{|c|}{ Immobilized enzyme } \\
\hline & & & & $\mathrm{pH} 11,95{ }^{\circ} \mathrm{C}$ & $\begin{array}{l}\text { Persulfate, } \mathrm{pH} \\
11,25^{\circ} \mathrm{C}\end{array}$ & $\begin{array}{l}\text { Peroxidase, } \mathrm{pH} \\
5,55^{\circ} \mathrm{C}\end{array}$ \\
\hline
\end{tabular}


protein and respectively the rate of peroxide generation was faster. However, its operational stability was not satisfactory, while the alumina support appeared to be appropriate for repeated application. Reuse of the immobilized on alumina support enzyme was affordable for at least three consecutive enzyme assays and high conversion of the substrate to peroxide was maintained. The enzymatically-produced hydrogen peroxide was activated for textile bleaching and the whiteness reached in the bleaching process was comparable to the whiteness reached with the chemically provided peroxide in a classical alkaline bleaching.

\section{References}

Asakura, T., Yoshimizu, H., Kuzuhara, A., Matsunaga, T, 1988. Mechanism of glucose oxidase immobilization with silk fibroin. J. Seric. Sci. Jpn. 57, 203-209.

Bosley, J.A., Peilow, A.D., 1997. Immobilization of lipases on porous polypropylene: reduction in esterification efficiency at low loading. J. Am. Oil Chem. Soc. 74, 107.

Bradford, M.M., 1976. A rapid and sensitive method for the quantitation of microgram quantities of protein utilizing the principle of protein-dye binding. Anal. Biochem. 72, 248254.

Costa, S., Tzanov, T., Paar, A., Gudelj, M., Gübitz, G., Cavaco-Paulo, A., 2001. Immobilization of catalases from Bacillus SF on alumina for the treatment of textile bleaching effluents. Enzyme Microb. Technol. 28, 815-819.

Damhus, T., Kirk, O., Pedersen, G., Venegas, M.G., 1991. Patent WO9105839A1.

Hartmeier, W., 1986. Immobilized Biocatalysts. Springer, Berlin, Heidelberg.

Hsiue, G., Wang, C., 1990. Glucose oxidase immobilized polyethylene-g-acrylic acid membrane for glucose oxidase sensor. Biotechnol. Bioeng. 36, 811-815.

Interox Chemicals Ltd., 1980. A Bleachers Handbook, Widnes, Cheshire, UK.

Letcher, T.M., Govender, P., Lutseke, S., 1994. Preparing cotton nonwoven fabrics at low temperatures using hydrogen peroxide activated with sodium persulfate. Textile Res. J. 64 (12), 761-764.
Mattiasson, B., Mosbach, K., 1976. Methods Enzymol. 44, 335. Messing, R.A., 1976. Methods Enzymol. 44, 148.

Morita, M., Ito, R., 1996. Kinetics of peroxidase catalysed decoloration of orange II with hydrogen peroxide. Textile Res. J. 66 (7), 470-473.

Oliveira, P.C., Alves, G.M., De Castro, H.F., 2000. Immobilisation studies and catalytic properties of microbial lipase onto styrene-divinylbenzene copolymer. Biochem. Eng. J. 5, 63-71.

Pramod, K., 1994. Patent US5288746.

Schacht, H., Kesting, W., Schollmeyer, E., 1995. Perspectiven enzymatischer Prozesse in der Textilveredlung. Textilveredlung 30, 237-243.

Soares, C.M.F., De Castro, H.F., De Moraes, F.F., Zanin, G.M., 1999. Characterization and utilization of Candida rugosa lipase immobilized on controlled pore silica. Appl. Biochem. Biotechnol. 77-79, 745-757.

Spirro, M.C., Criffith, P.W., 1997. The mechanism of hydrogen peroxide bleaching. Text. Chem. Color. 11 (29), 12.

Subramanian, A., Kennel, S., Oden, P., Jacobson, B.K., Woodward, J., Doktycz, M.J., 1999. Comparison of techniques for enzyme immobilization on silicone supports. Enzyme Microb. Technol. 24, 26-34.

Taylor, R.F., 1985. A comparison of various commerciallyavailable liquid chromatographic supports for immobilization of enzymes and immunoglobulins. Anal. Chim. Acta $172,241$.

Taylor, R.F., 1991. Protein Immobilization. Fundamentals and Applications. Marcel Dekker, Inc, New York.

Thomas, C.R., Dunnill, P., 1979. Action of shear on enzymes: studies with catalase and urease. Biotechnol. Biochem. 25, 14-18.

Tzanov, Tz., Calafell, M., Guebitz, G.M., Cavaco-Paulo, A., 2001a. Bio-preparation of cotton fabrics, Enzyme Microb. Technol. 29, in press.

Tzanov, T., Costa, S., Guebitz, G.M., Cavaco-Paulo, A., 2001 b. Effect of the temperature and bath composition on the dyeing with catalase treated bleaching effluents. Color. Technol. 117, 166-170.

Van der Helm et al., 1998. Patent WO98/28400.

Vasudevan, P.T., Thakur, D.S., 1994. Soluble and immobilized catalase effect of pressure and inhibition on kinetics and deactivation. Appl. Biochem. Biotechnol. 49, 173-189.

Weck, M., 1991. Hydrogen peroxide-an environmentally acceptable textile bleaching agent. Text. Praxis Int. 2, $144-147$.

Wilson, R., Turner, A.P.F., 1992. Glucose oxidase: an ideal enzyme. Biosens. Bioelectr. 7, 165-185. 